\title{
Impact of Intensity and Season of Grazing on Carbohydrate Reserves of Perennial Ryegrass
}

\author{
BABIKER EL HASSAN AND WILLIAM C. KRUEGER
}

\begin{abstract}
Carbohydrate reserves of perennial ryegrass declined during winter and early spring and began replenishment during seed formation. The primary reserve accumulation in roots occurred during fall growth, while crowns replenished about half of their reserves from seed formation to fall and the balance during fall. Total nonstructural carbohydrate (TNC) reserves in roots were highest following a relatively wet year when compared to an average year but carbohydrate reserves were found to be more concentrated in the average year. Biomass of storage organs had a greater effect than concentration of carbohydrates on TNC reserves. Complete protection of perennial ryegrass from grazing did not induce greater accumulation of carbohydrate reserves when compared to any season of grazing treatment and they were sometimes significantly lower than for grazed treatments. No advantage from deferment of grazing in spring, summer, or fall could be determined based on carbohydrate reserves as along as stocking intensity did not exceed one ewe per $650 \mathrm{~kg}$ of herbage production per year. At stocking rates above this, deferment during part of the growing season should be beneficial.
\end{abstract}

Rational management of rangelands involves a balanced relationship between the grazing animal and the forage resources. This relationship is a key factor in development of sound range management practices. Knowledge of plant response to various stocking intensities, season of grazing, and the interactions between these grazing parameters and the environmental complex is important for promoting a good management program. Hence, the growth attributes which play an essential role in development and productivity of plants should receive attention.

Carbohydrate reserves play a significant role in the phenology, vigor, development and productivity of plants. Exhaustion of reserves as a result of excessive defoliation has generally been associated with reduction in vigor and ultimately range deterioration. Characterization of reserves in the storage organs of plants can aid in detecting early symptoms of range deterioration before yield is seriously reduced.

In many areas of the world, perennial ryegrass (Lolium perenne) is a valuable pasture species; therefore, study of its physiology is of ecologic and economic interest (Silsbury 1971). It has been introduced to many temperate and Mediterranean regions. Ryegrass in mixture with white clover (Trifolium repens) constitutes the basis of pasture production in New Zealand and Australia (Harris and Thomas 1973). The fixation of nitrogen by the clover rhizobia con-

\footnotetext{
Authors are graduate student and associate professor, Rangeland Resources Program, Oregon State University, Corvallis, respectively. Dr. El Hassan is currently a member of the Faculty of Agriculture, University of Khartoum, Sudan.

This report was submitted as Technical Paper No. 5079. Oregon Agricultural Experiment Station, Corvallis.

The authors express appreciation to Dr. M.J. Trlica, Colorado State University, for his may helpful suggestions through the course of this study.

Manuscript received February 5, 1979
}

tributes to the observed beneficial association of the two species.

Perennial ryegrass has received considerable study by workers investigating its various physiological characteristics. However, the study of carbohydrate reserves in perennial ryegrass has been restricted to greenhouse experiments or to field research under artificial clipping and defoliation treatments.

This study was conducted on alluvial, well-drained, silt loam soils in the northern Willamette Valley of western Oregon. The climate is modified maritime with cool, wet winters and warm, dry summers and a long growing season. Precipitation is nearly all rain and averages about $102 \mathrm{~cm}$ per year. The wettest period, November through March, receives about $70 \%$ of the annual precipitation. About $5 \%$ of the annual precipitation falls from June through August. Temperatures are usually above freezing in winter, with only 52 days a year that minimum temperatures reach $0^{\circ} \mathrm{C}$. Summers are warm, and on the average 10 days a year will exceed $32^{\circ} \mathrm{C}$

This climatic pattern is suited for satisfactory growth of perennial ryegrass but is probably wetter in the winter and hotter in the summer than other parts of the world where perennial ryegrass is the dominant grass component of pastures.

\section{Methods and Procedure}

An area of 4.05 ha on a gentle north slope, $20 \mathrm{~km}$ north of Corvallis, Oregon, was divided into ten pastures of equal size. Nine pastures were used for study of seasonal grazing treatments and stocking intensities. The remaining pasture was completely protected from grazing and used for collecting samples at various phenological stages for determining the basic carbohydrate curve.

A split-split plot design was used and each grazing treatment was replicated three times. The stocking intensities were 7.4 ewes per ha (moderate), 9.9 ewes per ha (heavy), and 12.4 ewes per ha (very heavy). The grazing season was from April through December. Thetford (1976) determined that production from these pastures averaged $6,377 \mathrm{~kg} / \mathrm{ha} / \mathrm{yr}$ when not grazed and that there were no significant differences in potential yield of pastures stocked at these different intensities during the course of this study. Perennial ryegrass made up about $60 \%$ of the total production with the balance of vegetation dominated by annual grasses and forbs. Pastures were grazed each year at the assigned levels for 2 years before sampling for carbohydrate reserves was begun in 1974 .

\section{Sampling Procedure \\ Design}

Five circular cages of 0.69 diameter and and $1 \mathrm{~m}$ height were randomly placed in each of the nine pastures to prevent fall grazing. These cages, representing the Fall Protection Treatment, were kept in position until the spring season. Early in spring, an area with similar vegetation cover was selected near each of these cages. 
These five areas, which were open to fall grazing, were protected during the balance of the grazing season by transferring the cages from the Fall Protection Treatment. The newly caged areas were designated as the Fall Grazing Treatment. Following removal of the cages from the Fall Protection Treatment, these previously protected areas were inconspicuously marked and labelled for ease of future sampling.

Five cages were randomly placed in each of the nine pastures for the Complete Protection Treatment. All of the remaining open-tograzing parts of each pasture constituted the sampling area for the Season-Long Grazing Treatment. The tenth pasture was used for randomly collecting five samples of ryegrass roots and crowns at sequential stages of plant development.

\section{Root and Crown Sampling}

Roots and crowns of ryegrass for the four different seasons of grazing treatments were sampled during the months of July and August (period of quiescence) of the years 1974 and 1975. (Crowns are the lower portion of stems where internodes are not elongated. They were near the soil surface but unavailable for grazing). Typical ryegrass plants within each treatment were selected for study. Five samples per replication were collected by excavating plants to a depth of about $30 \mathrm{~cm}$. Roots and crowns of individual plants were collected from a vertical core. Diameter of the core varied depending upon the basal area of the individual plant being sampled. The perimeter of the core was located $5 \mathrm{~cm}$ from the base of the plant. We estimated that this procedure yielded about $80 \%$ of the total root biomass and that root collection was more complete for the very heavy grazing treatment.

Soil adhering to roots and crowns was removed by spraying with a stream of cold water over a fine mesh-screen immediately after collection. The roots and crowns of each sample were placed into two separate, clean, dry and previously weighed jars; covered with $95 \%$ ethanol to reduce enzymatic activity; and sealed tightly. These samples were transferred to an oven and dried at $70 \pm 2^{\circ} \mathrm{C}$.

Samples from the different treatments were collected for the determination of TNC concentration $(\mathrm{mg} / \mathrm{g})$ in the roots and crowns of each sample. Biomass of storage organs ( $\mathrm{mg} /$ plant) was computed by dividing the oven-dry weight of the original sample by the number of plants per sample. The product of TNC concentration and biomass gave total nonstructural carbohydrate per plant (mg/plant). Laboratory analysis followed the procedure reported by the Association of Official Agricultural Chemists (1965), Heinze and Murneek (1940) and Smith et al. (1964) and was calculated on a glucose equivalent basis.

An analysis of variance was carried out to help determine the impact of season of grazing, stocking intensities and years on the TNC concentration, biomass of storage organs, and TNC per plant. When significant differences among treatments were found, means were compared with Duncan's new multiple range test. The term significant refers to $p<.05$ unless otherwise stated.

\section{Results}

\section{Carbohydrate Reserve Cycle and Phenological Development}

Perennial ryegrass had well-defined seasonal trends in TNC concentration when related to stages of phenological development (Fig. 1). A similar pattern was shown by both roots and crowns. However, the crowns maintained a greater concentration of carbohydrates than was evident in roots. Weinmann (1948), Sprague and Sullivan (1950), Baker (1957), Coyne and Cook (1970), and Menke (1973) reported similar results for other perennial grasses.

Depletion of crown reserves occurred over a continuous period of about 4 months, winter regrowth in January to seed formation in May. Replenishment of crown reserves continued from seed formation through fall regrowth until December, with the exception of a slight decline during the period between the end of seed shatter and the beginning of fall regrowth. The greatest drawdown of root carbohydrate

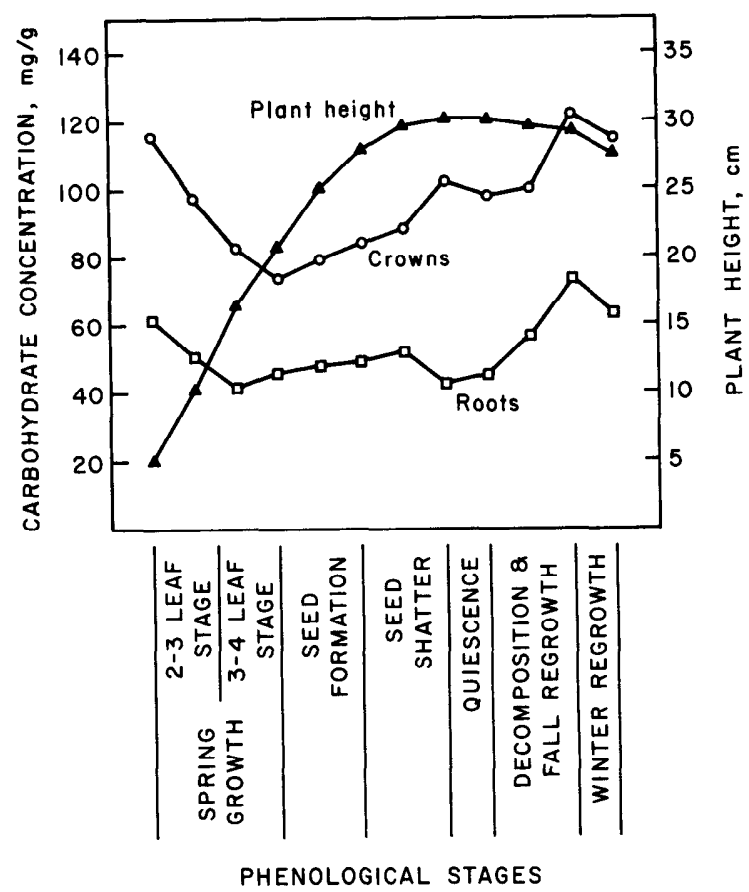

Fig. 1. Total nonstructural carbohydrate concentration $(\mathrm{mg} / \mathrm{g})$ and plant height $(\mathrm{cm})$ as related to phenological stages of perennial ryegrass.

reserves occurred about 1 month earlier than depletion in crown reserves.

\section{Carbohydrate Concentration}

In 1975 there was a significantly higher TNC concentration in both roots and crowns than in 1974 for all plants (Table 1). Precipitation was near normal in 1975 and about $30 \mathrm{~cm}$ above normal in 1974. The influence of stocking intensity on concentration of carbohydrate reserves was significant for both roots and crowns. There was a significant interaction $(p<0.01)$ among years and intensity of grazing as well as season and intensity of grazing for carbohydrate levels in roots, but not for crowns. Effects of season of grazing as well as the interaction between years and season of grazing were significant for both roots and crowns.

Table 1. Average total nonstructural carbohydrate concentration $(\mathrm{mg} / \mathrm{g})$ in storage organs of perennial ryegrass for main effects of year, intensity, and season of grazing.

\begin{tabular}{lll}
\hline & Roots & Crowns \\
\hline Year & & \\
1974 & $41^{\mathrm{al}}$ & $81^{\mathrm{a}}$ \\
1975 & $46^{\mathrm{b}}$ & $91^{\mathrm{b}}$ \\
Grazing intensity & & \\
Moderate & $43^{\mathrm{ab}}$ & $91^{\mathrm{a}}$ \\
Heavy & $46^{\mathrm{b}}$ & $85^{\mathrm{b}}$ \\
Very heavy & $41^{\mathrm{a}}$ & $82^{\mathrm{b}}$ \\
Season of grazing & & \\
CP & $41^{\mathrm{a}}$ & $82^{\mathrm{a}}$ \\
FP & $40^{\mathrm{a}}$ & $81^{\mathrm{a}}$ \\
FG & $47^{\mathrm{b}}$ & $95^{\mathrm{b}}$ \\
SG & $45^{\mathrm{ab}}$ & $86^{\mathrm{a}}$ \\
\hline
\end{tabular}

'Numbers in rows within storage organs followed by different superscripts are significantly different at $\mathrm{p}<.05$.

${ }^{2} \mathrm{CP}=$ Complete Protection

$\mathrm{FP}=$ Fall Protection

$\mathrm{FG}=$ Fall Grazing

SG $=$ Season-long Grazing 
Concentration of TNC in roots of perennial ryegrass for the very heavy stocking intensity was significantly lower than the heavy stocking intensity but not different than the moderate intensity (Table 1). Plants under the moderate stocking intensity had significantly higher crown carbohydrate concentration than those under each of the other two intensities. There was significantly higher TNC concentration in the roots of ryegrass sampled for the fall grazing treatment than either complete protection or fall protection treatments, but fall grazing results were not significantly different from those of season-long grazing. Ryegrass in the fall grazing treatment had a significantly higher carbohydrate concentration in the crowns than did ryegrass in any of the other three treatments.

\section{Biomass of Storage Organs}

Root biomass was significantly greater during 1974 than during 1975, but no differences existed for crowns (Table 2). Stocking intensity significantly affected crown weight, but did not affect root weight and both were significantly affected by season of grazing. No significant effect was shown for the interaction between stocking intensities and years for either root or crown biomass. The interactions between season of grazing and years and season of grazing and intensities were significant for both crown and root biomass. The interaction among season of grazing, intensity, and years was not significant for either root or crown biomass.

Table 2. Average biomass ( $\mathrm{mg} / \mathrm{plant}$ ) of storage organs of perennial ryegrass for main effects of year, intensity, and season of grazing.

\begin{tabular}{lcc}
\hline & Roots & Crowns \\
\hline Year & $123^{\mathrm{a} 1}$ & \\
1974 & $74^{\mathrm{b}}$ & $48^{\mathrm{a}}$ \\
1975 & & $48^{\mathrm{a}}$ \\
Grazing Intensity & $109^{\mathrm{a}}$ & \\
Moderate & $94^{\mathrm{a}}$ & $58^{\mathrm{a}}$ \\
Heavy & $94^{\mathrm{a}}$ & $49^{\mathrm{b}}$ \\
Very heavy & & $39^{\mathrm{c}}$ \\
Season of grazing 2 & & \\
CP & $103^{\mathrm{a}}$ & $40^{\mathrm{a}}$ \\
FP & $113^{\mathrm{b}}$ & $67^{\mathrm{b}}$ \\
FG & $85^{\mathrm{c}}$ & $40^{\mathrm{a}}$ \\
SG & $93^{\mathrm{c}}$ & $47^{\mathrm{a}}$
\end{tabular}

1 Numbers in rows within storage organs followed by different superscripts are significantly different at $\mathrm{p}<.05$.

${ }^{2} \mathrm{CP}=$ Complete Protection

$\mathrm{FP}=$ Fall Protection

$\mathrm{FG}=$ Fall Grazing

$\mathrm{SG}=$ Season-long Grazing

Ryegrass at moderate intensity had significantly greater crown biomass than when grazed at the other two intensities, while roots were not significantly affected by intensity of grazing (Table 2). The Fall Protection Treatment resulted in significantly greater root and crown biomass than each of the three other treatments.

\section{Carbohydrate Reserves Per Plant}

Roots had significantly greater TNC reserves per plant for 1974 than for 1975 when compared over all treatments, but no differences existed for crowns. Stocking intensity had a significant effect on the TNC reserves per plant for both the roots and crowns. The interaction between years and intensities were not significant.
Season of grazing significantly affected TNC reserves per plant in the crowns, but not in the roots. The interaction between intensity and season of grazing was significant for both roots and crowns. The interactions between treatments and years, and among treatments, intensities, and years were not significant for both plant parts.

Ryegrass grazed at the moderate stocking intensity had significantly higher root reserve per plant than those grazed at the very heavy stocking intensity (Table 3). Difference in root reserves for plants utilized under moderate and heavy stocking intensities were not significant. TNC of ryegrass crowns were significantly higher for plants grazed at moderate intensity when compared to those grazed under higher stocking rates. There were no significant differences in the TNC reserves per plant in the roots among all seasons of grazing treatments. However, crowns were influenced by season of grazing. The Season-Long Grazing Treatment had significantly higher TNC reserves in plant crowns than did the Complete Protection Treatment. There was no significant difference between the Season-Long Grazing Treatment and the Fall Grazing Treatment. The Fall Protection Treatment had significantly higher levels of reserves than each of the other treatments.

Table 3. Average total nonstructural carbohydrate reserves $(\mathrm{mg} / \mathrm{plant})$ in storage organs of perennial ryegrass for main effects of year, intensity, season of grazing.

\begin{tabular}{lll}
\hline \hline & Roots & Crowns \\
\hline Year & & \\
1974 & $5.0^{\mathrm{a} 1}$ & $3.9^{\mathrm{a}}$ \\
1975 & $3.4^{\mathrm{b}}$ & $4.4^{\mathrm{a}}$ \\
Intensity of Grazing & & \\
Moderate & $4.7^{\mathrm{a}}$ & $5.3^{\mathrm{a}}$ \\
Heavy & $4.3^{\mathrm{ab}}$ & $4.2^{\mathrm{b}}$ \\
Very heavy & $3.8^{\mathrm{b}}$ & $3.2^{\mathrm{c}}$ \\
Season of Grazing 2 & & \\
CP & & $3.3^{\mathrm{a}}$ \\
FP & $4.2^{\mathrm{a}}$ & $5.4^{\mathrm{c}}$ \\
FG & $4.5^{\mathrm{a}}$ & $3.8^{\mathrm{ab}}$ \\
SG & $4.0^{\mathrm{a}}$ & $4.0^{\mathrm{b}}$
\end{tabular}

'Numbers in rows within storage organs followed by different superscripts are significantly different at $\mathrm{p}<.05$.

${ }^{2} \mathrm{CP}=$ Complete Protection

FP $=$ Fall Protection

$\mathbf{F G}=$ Fall Grazing

SG $=$ Season-long Grazing

\section{Discussion}

\section{Reserves and Phenological Development}

The U-shaped curve displayed by perennial ryegrass for reserve depletion and replenishment in relation to phenological stages of development was in general agreement with findings and suggested trends for other perennial grasses (Cook 1966 and Menke 1973).

Fall regrowth did not result in a sharp decline in TNC reserves as did growth in spring and winter. It is possible that during fall depletion was minor and reserves were rapidly replenished after initiation of regrowth, or stem and leaf growing points had enough energy to reactivate growth.

The growth curve had its greatest slope during spring and winter stages of development, concurrent with reserve depletion. Other phases of growth showed a synchronized trend with the fluctuation in the reserves. The uninterrupted 
growth curve together with the obvious capacity for replenishment of carbohydrate reserves after depletion gave a physiological indication that perennial ryegrass is adapted to the prevailing conditions.

\section{Grazing Treatments}

Both concentration and biomass of storage organs influenced TNC reserves. However, biomass affected the magnitude of actual carbohydrate per plant more than did carbohydrate concentration. Baker (1957) reported that quantitative determination of TNC reserves probably gives a better indication of reserve distribution than estimates based only on concentration. He also found that the actual quantity of reserves did not vary as markedly as concentration.

Total precipitation in 1974 was $129 \mathrm{~cm}$ as compared to $100 \mathrm{~cm}$ for 1975 , which was near the long-term average. The higher precipitation in 1974 might have created favorable growth conditions not only for aboveground growth but also for underground plant parts. The higher root biomass for 1974 was probably a result of more favorable amounts of precipitation.

Season of grazing had a significant effect on the investigated attributes of both plant parts, except for TNC reserves per plant in the roots. Fall Protection allowed maximum accumulation of crown reserves and Season-long grazing resulted in significanlty more total carbohydrate reserves the Complete Protection, but not more than Fall Grazing. Complete protection of plots could have resulted in greater total plant competition. Thus carbohydrate reserves might have been depressed due to suboptimal growing conditions for ryegrass. Complete Protection was the only grazing treatment which never showed significantly higher carbohydrate reserves or greater biomass of storage organs when compared to the main effects of other grazing treatments. Hence, year-long protection did not appear to be of any physiological advantage to ryegrass. This high tolerance to all seasons of grazing may be utilized favorably for generating a flexible grazing program which meets the requirements of both perennial ryegrass and the grazing animal.

Research conducted concurrent with the present study showed that total yield of grazed or ungrazed ryegrass was not significantly different among the pastures stocked at these three intensities (Thetford 1976). However, field observations indicated ryegrass grazed season-long under very heavy stocking delayed active growth about 3 weeks in spring when compared to ryegrass under lighter season-long grazing intensities. It appeared that ryegrass under very heavy stocking was using reserves that would otherwise bc available for early spring growth. Therefore, the apparent annual production efficiency may, in reality, be leading to a longer term decline in production. This idea was supported by the significant grazing season and grazing intensity interaction. Under moderate and heavy grazing, TNC reserves were lowest under complete protection. The situation reversed under very heavy grazing where complete protection had the higher reserves. This relationship of reserves to subsequent growth was not apparent for TNC concentration levels. Consequently, it appeared total reserve level was a more sensitive indicator of carbohydrate reserves than was concentration of reserves.

Very heavy stocking intensities used in this study should not be detrimental to carbohydrate reserves of ryegrass if the grazing pressure was relaxed by shortening the overall period of spring grazing or providing a period of nonuse during the growing season. Stocking rates were set to allow moderate to very heavy use of forages during a 9-month grazing season rather than with respect to critical growth stages of development. If comparable pastures were grazed during only one or two seasons each year, then what was designated very heavy stocking might be proper. It follows that intensity, duration, and season of grazing should be considered concurrently.

\section{Management Implications}

The early spring growth phase of perennial ryegrass was characterized by declining levels of carbohydrate reserves, which were subsequently replenished under either moderate or heavy grazing. If no rotation is planned for the grazing season and ryegrass pastures are to be grazed at intensities comparable to the very heavy stocking treatment in this study, they should be deferred for about 2 weeks after the spring flush of growth commences. Grazing during summer is not detrimental to the carbohydrate reserves in the storage organs of perennial ryegrass since growth of new tissue is limited by moisture stress. Summer grazing also aids in the removal of litter. Excessive litter on the pasture retards growth of important legumes often grown in association with perennial ryegrass. Fall grazing was demanding on carbohydrate reserves, especially under very heavy stocking. Protection from very heavy fall grazing periodically should be beneficial for maintenance of total reserves.

Grazing of perennial ryegrass pastures from spring through fall at a stocking intensity of about one ewe per 650 kilograms of total herbage produced annually should allow maintenance of the ryegrass stand. If it is desired to stock at rates higher than indicated, then periodic deferment in either early spring or fall will probably be necessary to maintain perennial ryegrass productivity.

\section{Literature Cited}

Association of Official Agriculture Chemists. 1965. Official methods of analysis of the Association of Official Agriculture Chemists. 10th ed. Washington, D.C. p. 498-499.

Baker, H.K. 1957. Studies on the root development of herbage plants. III. The influence of cutting treatment on the root, stubble and herbage production of a perennial ryegrass sward. J. Br. Grassld. Soc. 12: 197 208.

Cook, C.W. 1966. Carbohydrate reserves in plants. Utah Agr. Exp. Sta. Resources Ser. 31.47 p.

Coyne, P.I., and C.W. Cook. 1970. Seasonal carbohydrate reserve cycles in eight desert range species. J. Range Manage. 23: 438-444.

Harris, W., and J.V. Thomas. 1973. Competition among pastures. III. Effects of frequency and height of cutting on competition between white clover and two ryegrass cultivars. N.Z. J. Res. 16: 49-58.

Heinze, P.H., and A.E. Murneek. 1940. Comparative accuracy and efficiency in determination of carbohydrates in plant material. Mo. Agr. Exp. Sta. Res. Bull. 314. 23 p.

Menke, J.W. 1973. Effect of defoliation on carbohydrate reserves, vigor and herbage yield for several important Colorado range specics. PhD thesis, Colorado State Univ., Fort Collins. 283 p.

Silsbury, J.H. 1971. The effects of temperature and light energy on dry weight and leaf area changes in seedling plants of Lolium perenne $\mathrm{L}$. Aust. J. Agr. Res. 22: 177-187.

Smith, D., G.M. Paulsen, and C.A. Raguse. 1964. Extraction of total available carbohydrates from grass and legume tissue. Plant Physiol. 39: 960-962.

Sprague, V.G., and J.T. Sullivan. 1950. Reserve carbohydrates in orchard grass clipped periodically. Plant Physiol. 25: 92-102.

Thetford, F.O. 1976. Responses of vegetation and sheep to three grazing pressures. PhD thesis, Oregon State Univ., Corvallis. $157 \mathrm{p}$.

Weinmann, H. 1948. Underground development and reserves of grasses. A review. J. Brit. Grassld. Soc. 3: 115-140. 